\title{
Effect of Fungal Infection on Defence Proteins of Musca domestica L. and Variation of Virulence with Temperature
}

\author{
1*SOYELU, OJ; ${ }^{1}$ OYERINDE, RM; ${ }^{1}$ ODU, BO; ${ }^{2}$ OKONJI, RE
}

\author{
${ }^{I}$ Department of Crop Production and Protection, Faculty of Agriculture, Obafemi Awolowo University, Ile-Ife 220005, Osun State, Nigeria. \\ ${ }^{2}$ Department of Biochemistry and Molecular Biology, Faculty of Science, Obafemi Awolowo University, Ile-Ife 220005, Osun State, Nigeria. \\ *Corresponding Author Email: jlekan2001@yahoo.co.uk; soyelu@oauife.edu.ng
}

\begin{abstract}
With the current global drive for alternative control measures that are safer in comparison to synthetic insecticides, it was considered necessary to assess some fungal entomopathogens for efficacy against the house fly, Musca domestica. The effect of fungal infection on activity of two detoxification enzymes (esterase [EST] and glutathione-S-transferase [GST]) was determined in the laboratory. Effect of temperature on progression of mycosis was also investigated between 15 and $35^{\circ} \mathrm{C}$ to determine the optimum temperature necessary for successful fungal infection. Two Beauveria bassiana strains (ARSEF 1564 and ARSEF 8891), Metarhizium robertsii (ARSEF 1057) and M. anisopliae s.s. (ARSEF 5471) were evaluated in this study as potential sources of mycoinsecticide formulations. The fungal strains infected larval and adult house flies successfully by inhibiting activity of EST and GST with a concomitant insect mortality of $>90 \%$. A significantly higher number of dead specimens $(80-100 \%)$ had fungal growth between 20 and $25^{\circ} \mathrm{C}$ with a noticeable level of mycosis also at $30^{\circ} \mathrm{C}$. The evaluated fungal strains showed good insecticidal efficacy and could, therefore, serve as good sources of mycoinsecticide formulations against house fly. If this area of biological control is well explored it would reduce reliance on synthetic insecticide formulations.
\end{abstract}

DOI: $\underline{\text { https://dx.doi.org/10.4314/jasem.v24i3.12 }}$

Copyright: Copyright $₫ 2020$ Soyelu et al. This is an open access article distributed under the Creative Commons Attribution License (CCL), which permits unrestricted use, distribution, and reproduction in any medium, provided the original work is properly cited.

Dates: Received: 16 November 2019; Revised: 11 January 2020; Accepted: 22 February 2020

Keywords: Defence proteins, house fly mortality, mycosis, optimum temperature

The common house fly, Musca domestica L. (Diptera: Muscidae), can be found in every place where people live and are also associated with animal husbandry. House flies are carriers of more than 65 human and animal intestinal diseases and they are responsible for protozoan (amoebic dysentery), bacterial (shigellosis, salmonellosis, cholera) and helminthic (round worms, hookworms, pinworms and tapeworms) infections (Sasaki et al., 2000). Miller et al. (1993) reported a significant reduction in poultry egg production due to a high population density of house fly. The major control strategy against house fly is application of synthetic insecticides but its associated problems such as pesticide resistance and environmental contamination are proofs that this pest is still a major problem and, thus, a cause for concern among researchers. Research efforts have been devoted to investigating non-chemical control strategies as alternatives to synthetic insecticides.

The non-chemical control alternatives include environmental sanitation (Moon, 2002), use of natural products (Bell et al., 2015) and biological control using parasitoids (Olbrich and King, 2003), predators (Paliy et al., 2018) and entomopathogenic fungi (Weeks et al., 2017). Interest in using fungi against house fly continues to grow among researchers probably due to abundance of fungal isolates in nature, ease of handling and relatively rapid rate of multiplication.
The virulence of fungal species, including Beauveria bassiana (Bals.) Vuill and Metarhizium anisopliae (Metsch.) Sorok. (Ascomycota: Hypocreales), to house fly has been reported by previous authors (e.g., Lecuona et al., 2005; Baker et al., 2018). Oyerinde (2017) reported $70 \%$ and $91 \%$ mortality among infected adult and larval house flies, respectively.

During the attack process, the host immune system attempts to resist the fungus, and some detoxification enzymes inside the insect play a part in protecting it from the negative impact of the pathogens and their toxins. General esterase (EST) and glutathione-Stransferase (GST) have been reported to be the most important detoxification enzymes but unlike their well-documented roles against toxic plant allelochemicals and pesticides, their activity during progression of mycosis is relatively unknown. An optimum temperature is germane to virulence of a fungal pathogen (Tefera and Pringle, 2003). Although temperature tolerance vary significantly among fungal isolates, optimum temperatures for germination, growth, sporulation and virulence of entomopathogenic fungi have been reported to range between 20 and $30^{\circ} \mathrm{C}$ (Dimbi et al., 2004; Kiewnick, 2006). This study was, therefore, designed to highlight the fate of EST and GST during the process of mycosis and to determine the associated optimum temperature for selected strains. 


\section{MATERIALS AND METHODS}

Fungal isolates: Two isolates of $\mathrm{B}$. bassiana (ARSEF 1564 and ARSEF 8891), Metarhizium robertsii (ARSEF 1057) and M. anisopliae s.s. (ARSEF 5471) from the USDA-ARS Biological Integrated Pest Management Research Unit, New York were bioassayed against larval and adult house flies. A comprehensive detail of how the fungi were reactivated from lyophilised form was reported by Oyerinde (2017). The fungal cultures were grown on potato-dextrose agar at $27^{\circ} \mathrm{C}$ for 7 days after which sporulating cultures were harvested by scraping the dry conidia with a scalpel and washing them with distilled water into sterile vials. An aqueous formulation was prepared $(10 \mathrm{ml})$ in a $0.1 \%$ Tween 80 solution. Conidia were counted using a haemocytometer to calibrate a concentration of $10^{8}$ conidia/ml for each fungal isolate.

Rearing of house fly: Adult house flies were reared in laboratory cages at $27^{\circ} \mathrm{C}, 45 \pm 5 \% \mathrm{RH}$ and $12: 12$ light: dark photoperiod. They were provided with sugar cubes and water was given in soaked cotton wool balls. Larvae were reared on moistened blended rice (carbohydrate) and fish (protein) in ratio 4:1 (w/w) as recommended by Cooper et al. (2004). This larval diet also served as oviposition substrate for adult flies. As a precautionary measure, food sources were renewed frequently to prevent fungal growth in the cages. Rearing cages were monitored daily and pupae were transferred into separate cages for adult emergence. The rearing procedure was repeated and third generation larvae and adult flies were selected for bioassays.
Preparation of enzyme extract: Groups of 3-4 days old adult house flies were provided, in separate cages, with granulated sugar treated with the conidial suspension of each fungal isolate while larvae were reared on inoculated rice-fish diet in replicated cages. The control experiment consisted of larvae and adult flies that were provided with distilled water-treated diet. On the seventh day of exposure, enzyme samples were prepared by homogenizing the larval and adult house flies in 3 volumes of sodium phosphate buffer $(\mathrm{pH} 7.5)$ followed by centrifugation at $4,000 \mathrm{rpm}$ for $30 \mathrm{~min}$ at $4^{\circ} \mathrm{C}$. The protein rich supernatants were collected and stored at $4^{\circ} \mathrm{C}$ in a refrigerator.

Determination of total protein: The protein concentration of each enzyme extract was determined according to the method of Bradford (1976) using bovine serum albumin as the standard. The reaction mixture consisted of $0.01 \mathrm{ml}$ tissue extract and $1.0 \mathrm{ml}$ Bradford reagent. The optical density was read at 595 nm.

Determination of esterase activity: The esterase activity was determined according to procedure of Lopes et al. (2011). A mixture of $5 \mathrm{ml}$ olive oil, $2 \mathrm{ml}$ $0.1 \mathrm{M}$ Phosphate buffer ( $\mathrm{pH} \mathrm{7.0)}$ and $1 \mathrm{ml}$ of the enzyme extract was incubated at $37^{\circ} \mathrm{C}$ for $30 \mathrm{~min}$ with orbital shaking. Immediately after incubation, the reaction was disrupted by the addition of $15 \mathrm{ml}$ acetone-ethanol mixture $(1: 1 \mathrm{v} / \mathrm{v})$ and the liberated free fatty acids were titrated with $0.05 \mathrm{M} \mathrm{NaOH}$. All assays were done independently and in triplicate. One unit of esterase activity was defined as the amount of enzyme which liberated $1 \mu \mathrm{mol}$ of fatty acids per minute and it was calculated as

$$
\text { Esterase activity }=\frac{\text { volume of } \mathrm{NaOH} \text { used } \times \text { molarity of } \mathrm{NaOH}}{\text { volume of enzyme } \times \text { incubation time }}
$$

Determination of glutathione-S-transferase activity: Activity of glutathione-S-transferase was determined as described by Vontas et al. (2000). Into a clean, dry test tube was pipetted $2.7 \mathrm{ml}$ sodium phosphate buffer $(0.1 \mathrm{M} ; \mathrm{pH} 6.5), 0.1 \mathrm{ml} 30 \mathrm{mM}$ reduced glutathione and $0.1 \mathrm{ml} 30 \mathrm{mM}$ 1-chloro-2,4-dinitrobenzene
(CDNB). To the resulting mixture, $0.2 \mathrm{ml}$ of insect hemolysate was added. The absorbance of the reacting mixture was measured at $340 \mathrm{~nm}$ at $15 \mathrm{~s}$ intervals for $3 \mathrm{~min}$. Distilled water $(0.2 \mathrm{ml})$ was used in lieu of hemolysate for the blank. The GST activity was calculated as

$$
\text { Glutathione }-\mathrm{S}-\text { transferase activity }=\frac{\Delta \mathrm{A} / \mathrm{min} \times \mathrm{DF} \times \mathrm{V}}{\mathrm{v} \times \Sigma}
$$

Where $\Sigma=$ extinction coefficient of CDNB $\left(9.6 \mathrm{mM}^{-1}\right.$ $\left.\mathrm{cm}^{-1}\right) ; \Delta \mathrm{A} / \mathrm{min}=$ change in absorbance per minute; $\mathrm{V}$ $=$ reaction volume; $\mathrm{DF}=$ dilution; $\mathrm{v}=$ sample volume

Effect of temperature on efficacy of fungal isolates: Larval and adult house flies were enclosed separately, in groups of ten, inside plastic containers with perforated lids and provided with diet inoculated with conidial suspension. The containers were incubated at $15,20,25,30$ and $35^{\circ} \mathrm{C}$ with each experimental trial having a fungal isolate replicated four times. Control experiments were arranged in a similar manner with distilled water-treated diet. The containers were observed daily and mortality was recorded for 7 days. Dead insects were transferred to separate Petri dishes lined with damp filter paper and mortality due to fungal infection was confirmed by the presence of hyphae and spores on the body surface. 
Statistical analysis: The data obtained from enzyme bioassays were subjected to analysis of variance (ANOVA) followed by separation of mean values using Tukey's HSD at 0.05 level of probability. Percentage mortality and proportion of insects showing mycotic symptoms in each trial were subjected to square root transformation before separate ANOVA was carried out followed by mean separation.

\section{RESULTS AND DISCUSSION}

There was no statistical difference in esterase activity between infected and uninfected larval and adult house flies whereas in the case of glutathione-S-transferase, enzyme activity was significantly lower in infected specimens (Table 1). As a result, neither of the two defense proteins was able to protect house flies nor prevent the progression of mycosis. Inhibition of EST and GST during the acute period of mycosis is an evidence of effective breakdown of host's defence system (Gillespie et al., 2000), eventually leading to death. Zibaee et al. (2011) suggested that the secondary metabolites produced by B. bassiana disable several immune mechanisms in insects, thus helping the fungus to overcome and kill its hosts. Generally, insect mortality was very high $(>90 \%)$ and it did not vary with temperature (Table 2 ) but the effectiveness of selected fungal strains in killing house fly was explained better by the results presented in Table 3. It is necessary that obtained data are interpreted with caution because temperature could also contribute to insect mortality.

Table 1: Responses of detoxification enzymes in infected larval and adult house flies

\begin{tabular}{lllll}
\hline \multirow{2}{*}{ Fungal isolate } & \multicolumn{2}{l}{ Esterase (M/min) } & \multicolumn{2}{l}{ Glutathione-S-transferase (U/m) } \\
\cline { 2 - 5 } & Larva & Adult & Larva & Adult \\
\hline ARSEF 1564 & $0.0017 \mathrm{ab}$ & $0.0024 \mathrm{a}$ & $0.0260 \mathrm{~b}$ & $0.4850 \mathrm{~b}$ \\
ARSEF 8891 & $0.0011 \mathrm{ab}$ & $0.0014 \mathrm{a}$ & $0.1000 \mathrm{~b}$ & $0.0650 \mathrm{~b}$ \\
ARSEF 1057 & $0.0007 \mathrm{~b}$ & $0.0033 \mathrm{a}$ & $0.1060 \mathrm{~b}$ & $0.0000 \mathrm{~b}$ \\
ARSEF 5471 & $0.0025 \mathrm{a}$ & $0.0015 \mathrm{a}$ & $0.0000 \mathrm{~b}$ & $0.7060 \mathrm{~b}$ \\
Distilled water & $0.0022 \mathrm{ab}$ & $0.0022 \mathrm{a}$ & $11.7900 \mathrm{a}$ & $11.7900 \mathrm{a}$ \\
\hline
\end{tabular}

Values with similar alphabets, within the same column, are not significantly different at 0.05 level of probability. ARSEF 1564 and ARSEF 8891: Beauveria bassiana; ARSEF 1057: Metarhizium robertsii; ARSEF 5471: M. anisopliae s.s.

Table 2: Percentage mortality of larval and adult house flies incubated at different temperatures in the laboratory

\begin{tabular}{|c|c|c|c|c|c|c|c|c|c|c|}
\hline \multirow[t]{2}{*}{ Fungal isolate } & \multicolumn{2}{|l|}{$15^{\circ} \mathrm{C}$} & \multicolumn{2}{|l|}{$20^{\circ} \mathrm{C}$} & \multicolumn{2}{|l|}{$25^{\circ} \mathrm{C}$} & \multicolumn{2}{|l|}{$30^{\circ} \mathrm{C}$} & \multicolumn{2}{|l|}{$35^{\circ} \mathrm{C}$} \\
\hline & Larva & Adult & Larva & Adult & Larva & Adult & Larva & Adult & Larva & Adult \\
\hline ARSEF 8891 & $96.30 \mathrm{a}$ & $100.00 \mathrm{a}$ & $95.56 \mathrm{a}$ & $100.00 \mathrm{a}$ & $93.35 \mathrm{a}$ & $94.75 \mathrm{a}$ & $97.16 \mathrm{a}$ & $100.00 \mathrm{a}$ & $97.54 \mathrm{a}$ & $100.00 \mathrm{a}$ \\
\hline ARSEF 5471 & $97.78 \mathrm{ab}$ & $100.00 \mathrm{a}$ & $96.30 \mathrm{ab}$ & $100.00 \mathrm{a}$ & $91.57 \mathrm{~b}$ & $98.89 \mathrm{ab}$ & $98.38 \mathrm{ab}$ & $100.00 \mathrm{a}$ & $96.53 \mathrm{ab}$ & $100.00 \mathrm{a}$ \\
\hline
\end{tabular}

Values with similar alphabets, within the same row, are not significantly different at 0.05 level of probability. ARSEF 1564 and ARSEF

8891: Beauveria bassiana; ARSEF 1057: Metarhizium robertsii; ARSEF 5471: M. anisopliae s.s.

Table 3: Percentages of dead house fly specimens with mycotic symptoms under five temperature regimes

\begin{tabular}{cllllllll}
\hline \multirow{2}{*}{ T $\left({ }^{\circ} \mathbf{C}\right)$} & \multicolumn{2}{l}{ ARSEF 1564 } & \multicolumn{2}{l}{ ARSEF 8891 } & \multicolumn{2}{l}{ ARSEF 1057 } & \multicolumn{2}{l}{ ARSEF 5471 } \\
\cline { 2 - 9 } & Larva & Adult & Larva & Adult & Larva & Adult & Larva & Adult \\
\hline 15 & $10.00 \mathrm{c}$ & $7.67 \mathrm{c}$ & $6.67 \mathrm{~d}$ & $10.00 \mathrm{c}$ & $10.00 \mathrm{c}$ & $16.67 \mathrm{~b}$ & $6.67 \mathrm{c}$ & $20.00 \mathrm{~b}$ \\
20 & $90.00 \mathrm{a}$ & $90.00 \mathrm{a}$ & $100.00 \mathrm{a}$ & $96.67 \mathrm{a}$ & $83.33 \mathrm{a}$ & $93.33 \mathrm{a}$ & $100.00 \mathrm{a}$ & $100.00 \mathrm{a}$ \\
25 & $87.33 \mathrm{a}$ & $86.67 \mathrm{a}$ & $93.33 \mathrm{a}$ & $89.67 \mathrm{a}$ & $80.00 \mathrm{a}$ & $96.67 \mathrm{a}$ & $100.00 \mathrm{a}$ & $96.67 \mathrm{a}$ \\
30 & $30.00 \mathrm{~b}$ & $40.00 \mathrm{~b}$ & $30.00 \mathrm{~b}$ & $40.00 \mathrm{~b}$ & $50.00 \mathrm{~b}$ & $20.00 \mathrm{~b}$ & $23.33 \mathrm{~b}$ & $26.67 \mathrm{~b}$ \\
35 & $16.67 \mathrm{c}$ & $10.00 \mathrm{c}$ & $16.67 \mathrm{c}$ & $10.00 \mathrm{c}$ & $0.00 \mathrm{~d}$ & $0.00 \mathrm{c}$ & $0.00 \mathrm{~d}$ & $0.00 \mathrm{c}$ \\
\hline
\end{tabular}

Values with similar alphabets, within the same column, are not significantly different at 0.05 level of probability. ARSEF 1564 and ARSEF 8891: Beauveria bassiana; ARSEF 1057: Metarhizium robertsii; ARSEF 5471: M. anisopliae s.s.

Thermal stress induces structural chromosome aberrations, increases frequency of micronuclei and affects development pattern in house fly (Mishra et al., 2013). Therefore, the presence of fungal growth on cadavers was taken as the sole index of mortality due to fungal infection. Though house fly mortality was comparable between 15 and $35^{\circ} \mathrm{C}$, mortality due to mycosis was highest $(80-100 \%)$ at $20-25^{\circ} \mathrm{C}$ and this was taken as the optimum temperature for selected fungal strains. It is, therefore, safe to speculate that cellular responses needed for fungal survival and progression of mycosis were initiated successfully within this temperature range. The obtained value falls within the $20-30^{\circ} \mathrm{C}$ optimum temperature established for entomopathogenic fungi in literature.
Conclusion: The effective pathogenic activity against the two stages of house fly was due, in part, to ability of fungal isolates to overcome detoxifying EST and GST thereby compromising the defense mechanism of house fly. The optimal $20-25^{\circ} \mathrm{C}$ together with the appreciable level of mycosis at $30^{\circ} \mathrm{C}$ makes the fungal isolates suitable for application in diverse environments. Successful formulation of effective mycoinsecticides from these fungi would help reduce reliance on synthetic insecticides, thereby creating a safer environment.

Acknowledgements: The authors are grateful to the USDA and ARS Plant Protection Research Unit for providing ARSEF 1564, 8891, 1057 and 5471 fungal 
cultures. Dr. Richard A. Humber, Insect Mycologist and former Curator of ARSEF, is also appreciated.

\section{REFERENCES}

Baker, DK; Rice, SJ; Leemon, DM; James, PJ (2018). Horizontal transmission of Metarhizium anisopliae (Hypocreales: Clavicipitacea) and the effects of infection on oviposition rate in laboratory populations of Musca domestica (Diptera: Muscidae). Pest Manag. Sci. 74: 987-991.

Bell, HA; Cuthbertson, AG; Audsley, N (2015). The potential use of allicin as a biopesticide for the control of the house fly, Musca domestica L. Int. J. Pest. Manag. 62: 111-118.

Bradford, MM (1976). A rapid and sensitive method for the quantitation of microgram quantities of protein utilizing the principle of protein-dye binding. Anal Biochem. 72: 248-254.

Cooper, TM; Mockett, RJ; Sohal, BH; Sohal, RS; Orr, WC (2004). Effect of caloric restriction on life span of the housefly Musca domestica. FASEB J. 18: 1591-1593.

Dimbi, S; Maniania, NK; Lux, SA; Mueke, JM (2004). Effect of constant temperatures on germination, radial growth and virulence of Metarhizium anisopliae to three species of African tephritid fruit flies. Biocontrol 49: 83-94.

Gillespie, JP; Burnett, C; Charnley, AK (2000). The immune response of the desert locust Schistocerca gregaria during mycosis of the entomopathogenic fungus Metarhizium anisopliae var acridum. J. Insect Physiol. 46: 429-437.

Kiewnick, S (2006). Effect of temperature on growth, germination, germ-tube extension and survival of Paecilomyces lilacinus strain 251. Biocontrol Sci. Technol. 16: 535-546.

Lecuona, RE; Turica, M; Tarocco, F; Crespo, DC (2005). Microbial control of Musca domestica (Diptea: Muscidae) with selected strains of Beauveria bassiana. J. Med. Entomol. 42(3): 332-336.

Lopes, DB; Fraga, LP; Fleuri, LF; Macedo, GA (2011). Lipase and esterase - to what extent can this classification be applied accurately? Ciênc Tecnol. Aliment. 31: 608-613.

Miller, RW; Pickens, LG; Potts, WE (1993). Comparison of traps and an integrated program to manage house flies and stable flies on dairy farms. J. Agric. Entomol. 10: 189-196.

Mishra, N; Tewari, RR; Srivastava, R (2013). Genotoxic effects of heat stress in house fly Musca domestica L. (Diptera: Muscidae). Int. J. Pharma. Bio. Sci. B 4(1): 455- 468.
Moon, RD (2002). Muscid flies (Muscidae). In: Mullen, GR and Durden, LA (eds) Medical and Veterinary Entomology 1st ed., Elsevier Science, USA, pp 279299.

Olbrich, DL; King, BH (2003). Host and habitat use by parasitoids (Hymenoptera: Pteromalidae) of house fly and stable fly (Diptera: Muscidae) pupae. Great Lakes Entomol. 36: 179-190.

Oyerinde, RM (2017). Biological control of the house fly, Musca domestica L. (Diptera: Muscidae), using four strains of entomopathogenic fungi. Unpublished M. Phil. Thesis, Obafemi Awolowo University, Osun State, Nigeria, pp 60, 2017.

Paliy, AP; Sumakova, NV; Paliy, AP; Ishchenko, KV (2018). Biological control of house flies. Ukr. J. Ecol. 8(2): 230-234.

Sasaki, T; Kobayashi, M; Agui, N (2000). Epidemiological potential of excretion and regurgitation by Musca domestica (Diptera: Muscidae) in the dissemination of Escherichia coli O157: H7 to food. J. Med. Entomol. 37: 945-949.

Tefera, T; Pringle, K (2003). Germination, radial growth, and sporulation of Beauveria bassiana to Chilo partellus (Lepidoptera: Pyralidae) at different temperatures. Biocontrol Sci. Technol. 3: 699-704.

Vontas, JG; Enayati, AA; Small, GJ; Hemingway, J (2000). A simple biochemical assay for glutathioneS-transferase activity and its possible field application for screening glutathione-S-transferasebased insecticide resistance. Pestic. Biochem. Physiol. 68: 184-192.

Weeks, ENI; Machtinger, ET; Gezan, SA; Kaufman, PE; Geden, CJ (2017). Effects of four commercial fungal formulations on mortality and sporulation in house flies (Musca domestica) and stable flies (Stomoxys calcitrans). Med. Vet. Entomol. 31: 15-22.

Zibaee, A; Bandani, AR; Talaei-Hassanlouei, R; Malagoli, D (2011). Cellular immune reactions of the sunn pest, Eurygaster integriceps, to the entomopathogenic fungus, Beauveria bassiana and its secondary metabolites. J. Insect Sci. 11: 138. 